\title{
Penggunaan Tanda Tangan Berubah-Ubah oleh Penghadap di dalam Pembuatan Akta Notaris
}

\author{
Ida Bagus Putu Pramarta Wibawa ${ }^{1}$
}

1Program Studi Magister (S2) Kenotariatan Fakultas Hukum Universitas Udayana, BaliIndonesia, E-mail: wibawa.pramarta@gmail.com

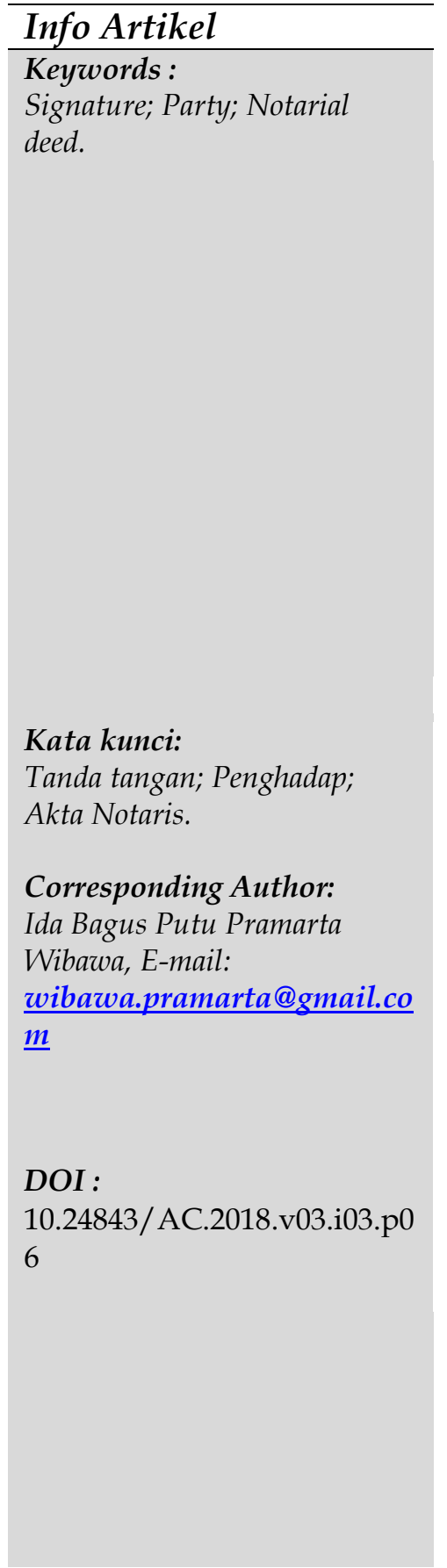

\begin{abstract}
The purpose of this research is to reviewe and analyze the extent to which the applicable laws and regulations in Indonesia regulate the use of signatures change by the partys in making notary deeds and to review and analyze the legal consequences of the use of signatures change by the partys in making a notary deed. This research is a normative legal research, using two types of approaches, namely the statute approach and the conceptual approach. The results of this study show that there are various causes of changing signatures of party, but the laws and regulations that apply in Indonesia do not have articles that govern this. The validity of a signature is seen based on the acknowledgment to justify the person affixing the signature. A different or change signature is justified by law insofar as the signer affixing his signature confirms that it is his signature, so that the legal consequences of such notary deeds are still valid to be used as evidence of authentic writing that has the power of perfect proof law.
\end{abstract}

\begin{tabular}{l} 
Abstrak \\
\hline Tujuan dari dilakukannya penelitian ini adalah untuk mengkaji \\
dan menganalisis mengenai sejauh mana peraturan perundang- \\
undangan yang berlaku di Indonesia mengatur mengenai \\
penggunaan tanda tangan berubah-ubah oleh penghadap di \\
dalam pembuatan akta notaris dan untuk mengkaji dan \\
menganalisis mengenai akibat hukum dari digunakannya tanda \\
tangan berubah-ubah oleh penghadap di dalam pembuatan akta \\
notaris. Penelitian ini merupakan penelitian hukum normatif, \\
dengan menggunakan dua jenis pendekatan yaitu pendekatan \\
perundang-undangan dan pendekatan konseptual. Hasil \\
penelitian ini menunjukkan bahwa ada berbagai penyebab \\
terjadinya tanda tangan yang berubah-ubah dari penghadap, \\
namun peraturan perundang-undangan yang berlaku di \\
Indonesia tidak terdapat pasal yang mengatur mengenai hal \\
tersebut. Keabsahan dari suatu tanda tangan adalah dilihat \\
berdasarkan adanya pengakuan untuk membenarkan dari orang \\
yang membubuhkan tanda tangan. Tanda tangan yang berbeda \\
atau berubah-ubah dibenarkan oleh hukum sepanjang penghadap \\
yang membubuhkan tanda tangannya tersebut membenarkan \\
bahwa itu adalah tanda tangannya, sehingga akibat hukum \\
terhadap akta notaris yang demikian adalah tetap sah untuk \\
digunakan sebagai alat bukti tulisan otentik yang memiliki \\
kekuatan hukum pembuktian sempurna.
\end{tabular}




\section{Pendahuluan}

Salah satu faktor yang mendorong masyarakat untuk menuangkan kehendaknya melalui akta yang dibuat di hadapan notaris karena masyarakat telah mempunyai kesadaran hukum yang tinggi. Sehingga pada saat ini sangat banyak bentuk perjanjian yang dibuat oleh masyarakat berbentuk akta notaris. ${ }^{1}$ Dengan masyarakat membuat akta di hadapan notaris maka notaris akan memberikan kepastian hukum mengenai perbuatan hukum yang dilakukan oleh penghadap serta akan memberikan perlindungan hukum kepada para penghadap, dimana akta notaris yang dibuat tersebut akan melindungi penghadap untuk dapat digunakan sebagai suatu alat bukti di kemudian hari apabila terjadi sengketa di antara para pihak. Berdasarkan hal tersebut pula maka jabatan notaris dikatakan sebagai suatu jabatan yang mulia (nobile officium) karena jabatan notaris sangat erat hubungannya dengan kemanusiaan. ${ }^{2}$

Undang-Undang Republik Indonesia Nomor 30 Tahun 2004 Tentang Jabatan Notaris (selanjutnya disebut UUJN), sebagaimana telah diubah dengan Undang-Undang Republik Indonesia Nomor 2 Tahun 2014 Tentang Perubahan Atas Undang-Undang Nomor 30 Tahun 2004 Tentang Jabatan Notaris (selanjutnya disebut UUJN Perubahan) adalah dua peraturan perundang-undangan di Indonesia yang mengatur mengenai jabatan notaris. Pada ketentuan Pasal 1 angka 1 UUJN Perubahan mengatur bahwa yang dimaksud dengan notaris adalah seorang pejabat umum yang mempunyai kewenangan untuk membuat akta otentik dan mempunyai kewenangan yang lain sebagaimana UUJN mengaturnya atau berdasarkan undang-undang lainnya. Berdasarkan pengertian tersebut bagi para pihak yang berkepentingan yang ingin membuat suatu alat bukti yang otentik maka hal tersebut adalah tugas notaris sebagai pejabat umum di dalam menjalankan sebagian kewenangan milik negara. ${ }^{3}$

Akta yang dibuat oleh notaris merupakan suatu akta otentik yang berarti kekuatannya sempurna untuk dapat digunakan sebagai suatu alat bukti dan tidak dibutuhkan alat bukti lain untuk menunjangnya. Apabila nantinya ada pihak yang membantah mengenai otentisitas dari suatu akta notaris maka pihak tersebut di depan pengadilan wajib untuk membuktikan sebaliknya. Akta notaris sebagai suatu akta otentik dapat dibedakan menjadi dua jenis yaitu:

1. Akta yang dibuat oleh (door) notaris atau sering disebut sebagai akta relaas atau akta pejabat (ambtelijke akten);

2. Akta yang dibuat di hadapan (ten overstaan) notaris atau sering disebut sebagai akta para pihak (partij akten). ${ }^{4}$

\footnotetext{
${ }^{1}$ Mahmoud, A. R. (2014). Implikasi Hukum Bagi Notaris Yang Tidak Melekatkan Sidik Jari Penghadap Pada Minuta Akta. Kumpulan Jurnal Mahasiswa Fakultas Hukum, 1(1), h. 4.

2 Prawira, M. A. S., \& Dewi, A. I. A. A. (2013). Kekuatan Pembuktian Akta Dibawah Tangan Yang Dilegalisasi Notaris Denpasar. Kertha Semaya, 1(05), h. 2.

3 Suwignyo, H. (2009). Keabsahan Cap Jempol sebagai Pengganti Tanda Tangan dalam Pembuatan Akta Otentik. Notarius, 1(1), h. 1.

${ }^{4}$ Puryatma, P. I. M. (2016). Teknik Dasar Pembuatan Akta Notaris. Denpasar: Tanpa Penerbit, h. 5.
} 
Pada akta relaas (ambtelijke akten) maka di dalam aktanya notaris akan menceritakan mengenai kesaksiannya terkait jalannya suatu peristiwa yang dilihat dan didengarnya. Sedangkan pada akta para pihak (partij akten) maka yang menjadi isi akta adalah memuat kehendak dan kemauan dari para pihak yang dituangkan oleh notaris. Penandatanganan oleh para pihak pada akta relaas (ambtelijke akten) bukan merupakan keharusan. Akta relaas tetap sah sebagai akta otentik meskipun para pihak tidak menandatangani akta relaas tersebut. Misalnya saja pada pembuatan Akta Berita Acara Rapat Umum Pemegang Saham, apabila para pihak telah meninggalkan rapat sebelum pihak tersebut menandatangani akta relaas maka notaris hanya wajib untuk menerangkan alasan di dalam akta yang dibuatnya bahwa pihak yang bersangkutan sebagai peserta rapat telah meninggalkan rapat sebelum menandatangani akta.

Hal tersebut di atas tidak dapat diterapkan pada akta para pihak (partij akten). Pada akta para pihak (partij akten) penandatanganan oleh para penghadap merupakan suatu keharusan. Setelah notaris selesai menuangkan kehendak dan kemauan dari penghadap di dalam aktanya maka kemudian bagi penghadap yang bersangkutan berkewajiban untuk membubuhkan tanda tangannya di bawah akta tersebut. Apabila penghadap tidak membubuhkan tanda tangannya maka akta para pihak (partij akten) tersebut akan kehilangan otentisitasnya sebagai suatu akta otentik. ${ }^{5}$

Di dalam penandatanganan akta para pihak (partij akten) di hadapan notaris terdapat beberapa hal yang menyebabkan penghadap yang bersangkutan di dalam membubuhkan tanda tangannya di bawah suatu akta di hadapan notaris menggunakan tanda tangan yang berbeda dari tanda tangan yang sebelumnya telah dipergunakannya atau terjadi perubahan tanda tangan. Namun peraturan perundang-undangan yang berlaku di Indonesia tidak terdapat pasal yang mengatur mengenai pembubuhan tanda tangan yang berubah-ubah oleh penghadap di dalam pembuatan akta di hadapan notaris tersebut.

Tujuan dari studi ini adalah untuk mengkaji dan menganalisis mengenai sejauh mana peraturan perundang-undangan yang berlaku di Indonesia mengatur mengenai penggunaan tanda tangan berubah-ubah oleh penghadap di dalam pembuatan akta di hadapan notaris dan untuk mengkaji dan menganalisis mengenai akibat hukum dari digunakannya tanda tangan berubah-ubah oleh penghadap di dalam pembuatan akta di hadapan notaris.

Penulis telah membandingkan penelitian-penelitian sebelumnya yang juga membahas mengenai tanda tangan pada suatu akta notaris. Tidak ditemukan karya tulis lainnya dengan judul maupun permasalahan yang sama dengan tulisan penulis. Terdapat penulis lain yang juga tertarik untuk membuat tulisan dengan tema tanda tangan pada suatu akta notaris. Misalnya tulisan pada Tesis Magister Kenotariatan Fakultas Hukum Universitas Udayana pada tahun 2014 yang ditulis oleh Ketut Mita Arishanti dengan judul "Kekuatan Hukum Cap Jempol Sebagai Tanda Tangan dalam Akta Notaris". Adapun tulisan pada tesis tersebut fokus pembahasannya mengenai penggunaan cap jempol oleh penghadap yang menggantikan keberadaan tanda tangan di dalam

${ }^{5}$ Ibid, h. 6. 
pembuatan akta notaris, sehingga tulisan pada tesis tersebut berbeda dengan tulisan yang ditulis penulis.

\section{Metode Penelitian}

Penelitian ini merupakan penelitian hukum normatif. Penelitian hukum normatif adalah penelitian untuk menemukan asas-asas hukum berdasarkan pada kaidah hukum atau norma-norma di dalam peraturan perundang-undangan. Dengan menggunakan dua pendekatan yaitu pendekatan perundang-undangan (the statute approach) dan pendekatan konsep (the conceptual approach). Untuk menjawab permasalahan yang terdapat di dalam penelitian ini maka penulis mendasarkan pada sumber-sumber penelitian yang disebut dengan bahan hukum. Bahan hukum di dalam penelitian hukum normatif dapat berupa bahan hukum primer, bahan hukum sekunder, dan bahan hukum tersier. Adapun metode pengumpulan bahan hukum dilakukan dengan sistem kartu (card system). Sistem kartu adalah dari studi kepustakaan yang dilakukan kemudian akan digunakan kartu kutipan yang kemudian dicatat dan dikutip beserta sumbernya. Bahan-bahan hukum yang telah terkumpul tersebut kemudian akan dianalisa dengan menggunakan metode konstruksi analisis dengan hasil penelitian yang disajikan secara deskriptif. Disajikan secara deskriptif disini berarti menguraikan atau melukiskan apa adanya terhadap suatu hal. ${ }^{6}$

\section{Hasil dan Pembahasan}

\subsection{Penggunaan Tanda Tangan Berubah-Ubah oleh Penghadap di dalam Pembuatan Akta Notaris}

\subsubsection{Fungsi Tanda Tangan Penghadap di dalam Pembuatan Akta Notaris}

Tanda tangan merupakan sesuatu hal yang tidak asing lagi ditemukan pada kehidupan manusia saat ini. Bahwa berdasarkan sejarah maka tanda tangan pertama kali muncul pada zaman Romawi. Awalnya di Romawi suatu kehendak seseorang tidak ditetapkan dengan suatu tulisan, melainkan cukup dilakukan secara lisan dihadapan saksi-saksi. Kehendak pertama yang dibuat dalam bentuk tertulis adalah surat wasiat, namun pada pembuatan surat wasiat ini juga masih belum menggunakan tanda tangan baik dari pembuat surat wasiat maupun dari saksi-saksi. Pembuatan surat wasiat tersebut hanya menggunakan sebuah segel yang dimaksudkan untuk memberikan suatu autentisitas. Tanda tangan digunakan pertama kali pada zaman Kaisar Justitianus, dimana menurut Kaisar Justitianus segel saja tidak lah cukup melainkan wajib pula diikuti dengan penandatanganan dari pembuat surat wasiat dan saksi-saksi. Adapun tanda tangan para saksi ini dimaksudkan untuk menunjuk orang-orang yang dapat memberi kesaksian apabila ada sengketa mengenai surat tersebut di pengadilan. ${ }^{7}$

Pada akta notaris di Perancis juga tidak diperlukan adanya suatu penandatanganan. Bukti autentisitasnya hanyalah segel kerajaan (le scel royal) yang dilekatkan oleh notaris setelah akta diselesaikan. Namun karena segel dari kerajaan tersebut tidak memberikan jaminan terhadap pemalsuan dan penipuan, maka ordonansi tahun 1304 dari Raja Perancis Philips den Schoonen memerintahkan kepada para notaris untuk menandatangani akta mereka. Hanya tanda tangan notaris yang dapat membuktikan autentisitas sebuah akta notaris dan berlangsung sampai tahun 1560. Setelah tahun 1560

\footnotetext{
${ }^{6}$ Mezak, M. H. (2006). Jenis, Metode dan Pendekatan Dalam Penelitian Hukum. Law Review: Fakultass Hukum Universitas Harapan, 5(3), h. 88.

${ }^{7}$ Kie, T. T. (2011). Studi Notariat Serba-Serbi Praktek Notaris. Jakarta: PT. Ichtiar Baru Van Houve, h. 473.
} 
ordonansi Karel IX di Perancis menentapkan bahwa tanda tangan notaris saja tidaklah cukup dan diperlukan tanda tangan para pihak diatas akta dan para pihak diwajibkan untuk turut serta menandatangani akta tersebut. ${ }^{8}$

Di negara Inggris mengenai syarat lahiriah suatu tanda tangan, maka bangsa Saks yaitu penghuni tertua di Inggris mempunyai kebiasaan untuk menandatangani suatu perjanjian dengan menulis namanya (untuk mereka yang dapat menulis) ditambah dengan sebuah salib (kruis, cross) karena mereka sudah memeluk agama Kristen. Sedangkan bagi mereka yang tidak dapat menulis maka hanya membubuhkan tanda salib (kruis, cross) saja. Kemudian di Belanda pada tahun 1892 kebiasaan untuk membubuhkan salib di bawah suatu tulisan bagi seseorang yang tidak dapat menulis berasal dari kebiasaan dari orang Saks tersebut. ${ }^{9}$

Di dalam peraturan perundang-undangan di Indonesia tidak terdapat ketentuan yang memberikan definisi dari apa yang dimaksud dengan tanda tangan. Tanda tangan dalam bahasa Inggris adalah handtekening, signature. Kata "menandatangani" sendiri berasal dari bahasa Belanda yaitu "ondertekenen" yang mana kata "menandatangani" secara etimologis berarti memberi tanda (teken) dibawah sesuatu. Terjemahan dari bahasa Belanda ondertekenen adalah "membuat tanda di bawah". Jadi "membuat tanda" tersebut haruslah "di bawah" sesuatu, dan sesuatu tersebut adalah tulisan. Di dalam kamus hukum tidak ditemukan definisi mengenai apa yang dimaksud dengan tanda tangan. Menurut Kamus Besar Bahasa Indonesia adapun definsi tanda tangan adalah tanda sebagai lambang nama yang dibuat secara tetap untuk keperluan tertentu. Sedangkan yang dimaksud dengan "penandatanganan" adalah membubuhkan nama dari si penandatangan, sehingga membubuhkan paraf, yaitu singkatan tanda tangan saja dianggap belum cukup. ${ }^{10}$

Menurut Pitlo sebagaimana dimuat di dalam buku Yahya Harahap maka bertitik tolak dari praktek maupun putusan Hoge Raad terdapat berbagai bentuk tanda tangan yang dibenarkan hukum, antara lain:

1. Menuliskan nama penanda tangan dengan atau tanpa menambah nama kecil;

2. Tanda tangan dengan cara menuliskan nama kecil saja, dianggap cukup;

3. Ditulis tangan oleh penanda tangan, tidak dibenarkan dengan stempel dengan huruf cetak;

4. Dibenarkan mencantumkan kopi tanda tangan milik si penanda tangan, dengan syarat orang yang mencantumkan kopi tersebut berwenang untuk itu dalam hal ini adalah orang yang bersangkutan sendiri atau orang yang mendapat mandat atau kuasa dari pemilik tanda tangan;

5. Dapat juga mencantumkan tanda tangan dengan mempergunakan karbon. ${ }^{11}$

Berdasarkan uraian tersebut di atas maka tanda tangan merupakan pencantuman identitas penanda tangan dalam surat yang bersangkutan. Tanda tangan sama artinya mencantumkan nama atau nama kecil yang ditulis dengan tangan sendiri oleh penanda

\footnotetext{
8 Ibid, h. 474.

${ }^{9} \mathrm{Ibid}, \mathrm{h} .475$.

${ }^{10}$ Mertokusumo, S. (2009). Hukum Acara Perdata Indonesia. Yogyakarta: Liberty, h. 152.

11 Harahap, M. Y. (2009). Hukum Acara Perdata Tentang Gugatan, Persidangan, Penyitaan, Pumbuktian, dan Putusan Pengadilan. Jakarta: Sinar Grafika, h. 561.
} 
tangan tanpa mengurangi kebolehan mencantumkan kopi tanda tanda tangan asal dilakukan oleh pemilik tanda tangan atau mendapat kuasa dari pemilik tanda tangan. Demi efisiensi maka pada masa sekarang penandatanganan surat atau akta yang terdiri dari beberapa lembar yang sama, maka hanya satu lembar yang pertama saja yang ditandatangani secara langsung, sedangkan duplikatnya sebagai lembar kedua dan seterusnya oleh hukum dibernarkan untuk dilakukan dengan menggunakan kertas karbon.

Sedangkan yang tidak termasuk atau yang tidak diakui keabsahannya sebagai suatu tanda tangan adalah tanda yang terdiri atas hal sebagai berikut:

1. Hanya berupa huruf atau abjad. Misalnya hanya terdiri dari huruf A sampai Z baik ditulis dalam huruf kapital maupun huruf kecil. Hal tersebut bukan dianggap sebagai inisial atau identitas dari si penanda tangan;

2. Tanda silang atau garis lurus. Tidak sah karena tidak bisa memberi identitas yang jelas kepada penanda tangan;

3. Stempel dengan huruf cetak. Bentuk ini dianggap tidak membubuhi syarat formil tanda tangan karena tidak dituliskan dengan tangan sendiri dari penanda tangan. Dengan stempel maka secara formil bukan dianggan sebagai tulisan (handschift) sebagaimana diatur Pasal 1874 KUH Perdata.

4. Ketikan dengan komputer. Tulisan atau akta yang dibubuhi tanda tangan dalam bentuk ketikan komputer adalah tidak sah, karena bukan merupakan tanda tangan sendiri dari penanda tangan. ${ }^{12}$

Menurut Tan Thong Kie adapun fungsi dari penghadap membubuhkan tanda tangannya di bawah suatu akta yang dibuat di hadapan notaris adalah sebagai suatu pernyataan kemauan dari penghadap yang membubuhkan tanda tangannya, bahwa penghadap tersebut dengan ia membubuhkan tanda tangannya di bawah suatu tulisan menghendaki agar tulisan tersebut oleh hukum dianggap sebagai tulisannya sendiri. Tan Thong Kie menambahkan bahwa tanda tangan seseorang harus mempunyai sifat individual (individueel character) dalam bentuk huruf yang ditulisnya, sehingga setiap tanda tangan yang ditulis dengan tangannya sendiri memenuhi syarat-syarat tentang bentuk suatu penandatanganan yang sah. ${ }^{13}$

Berdasarkan uraian tersebut maka fungsi dari adanya tanda tangan dalam suatu akta notaris adalah untuk mengindividualisir atau memberi ciri suatu akta yang dibuat oleh penghadap dan pembubuhan tanda tangan tersebut juga berfungsi sebagai suatu pernyataan kemauan atau persetujuan. Adapun fungsi mengindividualisir suatu akta adalah untuk membedakan akta yang satu dengan akta yang lainnya atau dari akta yang dibuat penghadap lain. ${ }^{14}$ Keberadaan suatu tanda tangan sangat penting untuk memverifikasi suatu dokumen karena dengan adanya tanda tangan tersebut dapat menjadi penanda atau identitas yang ada pada suatu dokumen. ${ }^{15}$ Yang dimaksud disini adalah mengingat di dalam pembuatan akta notaris sebagai akta otentik terdapat kemungkinan bahwa terdapat persamaan dari jenis-jenis akta yang dibuat maupun

$12 \mathrm{Ibid}, \mathrm{h} .562$.

${ }^{13}$ Kie, T. T. Op.cit. h. 476.

${ }_{14}^{14}$ Mertokusumo, S. Op.cit, h. 151.

${ }^{15}$ Arifin, J., \& Naf'an, M. Z. (2017). Verifikasi Tanda Tangan Asli Atau Palsu Berdasarkan Sifat Keacakan (Entropi). Jurnal Infotel, 9(1), h. 1. 
persamaan di antara para penghadap baik itu persamaan nama, persamaan alamat, persamaan pekerjaan dan lain-lain, maka disinilah diperlukan adanya suatu tanda tangan agar dapat membedakan antara akta yang satu dengan akta yang lainnya dan agar dapat membedakan antara orang atau penghadap yang satu dengan orang atau penghadap yang lainnya yang memiliki persamaan-persamaan sebagaimana diuraikan tersebut. Adanya persamaan diantara para penghadap akan dibedakan dari tanda tangan yang memiliki sifat mengindividualisir tersebut, karena setiap penghadap akan memiliki gaya tanda tangan dan tulisan yang berbeda-beda (memberikan ciri pembeda). Adapun maksud dari fungsi tanda tangan sebagai suatu pernyataan kemauan atau persetujuan adalah dengan penghadap telah membubuhkan tanda tangannya di bawah suatu tulisan atau akta maka ia dianggap telah mensetujui dan mengerti mengenai tulisan yang ada diatasnya, sehingga dengan demikian penghadap yang telah membubuhkan tanda tangannya tersebut secara otomatis akan terikat oleh isi dari akta yang dibuatnya.

Akta notaris merupakan akta otentik yang berarti bahwa akta notaris sebagai alat bukti terkuat dan terpenuh sepanjang tidak terdapat pihak lain yang menyangkal mengenai kebenaran dari isi akta tersebut. Pembubuhan tanda tangan penghadap di bawah tulisan atau akta yang dibuat di hadapan notaris merupakan hal yang sangat penting. Pembubuhan tanda tangan dari penghadap di dalam suatu akta notaris dikatakan hal yang penting karena keberadaan tanda tangan dari penghadap merupakan hal yang mutlak dan wajib ada, dimana suatu surat atau tulisan yang memuat pernyataan atau kesepakatan yang jelas dan terang tetapi tidak ditandatangani maka apabila ditinjau dari segi hukum pembuktian, tidak sempurna sebagai surat atau akta sehingga tidak sah dipergunakan sebagai alat bukti tulisan. Ketika surat tersebut merupakan suatu pernyataan sepihak maka wajib untuk ditandatangani oleh orang yang membuat pernyataan, sedangkan apabila suatu surat tersebut merupakan kesepakan di antara dua belah pihak maka wajib untuk ditandatangani oleh dua belah pihak. ${ }^{16}$ Apabila akta notaris yang memuat suatu pernyataan atau kesepakatan tersebut tidak terdapat tanda tangan dari penghadap, dimana penghadap tidak membubuhkan tanda tangannya pada akta yang dibuatnya maka apabila ditinjau dari segi hukum pembuktian akta notaris yang dibuat tersebut tidak sempurna sebagai akta, sehingga tidak dapat digunakan sebagai alat bukti tulisan yang otentik di kemudian hari apabila terjadi sengketa. Oleh karena itu supaya akta notaris tersebut dapat digunakan sebagai alat bukti tulisan yang otentik apabila terjadi sengketa di kemudian hari maka wajib terdapat tanda tangan dari para penghadap, saksi-saksi, dan notaris pada bagian akhir akta.

\subsubsection{Pengaturan Penggunaan Tanda Tangan Berubah-Ubah oleh Penghadap di dalam Pembuatan Akta Notaris}

Setiap subjek hukum di dalam melakukan sesuatu perbuatan hukum memerlukan suatu hal yang dapat dijadikan alat bukti di kemudian hari apabila terjadi sengketa. Adapun yang dimaksud dengan alat bukti adalah sesuatu yang dipergunakan untuk menentukan kebenaran fakta-fakta hukum di dalam suatu penyelidikan maupun

${ }^{16}$ Harahap, M. Y. Op.cit, h. 560. 
persidangan. ${ }^{17}$ Alat bukti adalah alat untuk membuktikan kebenaran hubungan hukum yang dinyatakan baik oleh penggugat maupun oleh tergugat dalam perkara perdata. Apakah sesuatu itu merupakan alat bukti, maka tidak tergantung dari diajukannya sesuatu itu dalam persidangan, tetapi ditentukan oleh sifatnya dan tidak ditetapkan oleh kenyataan apakah sesuatu itu diajukan atau tidak diajukan di persidangan. Jadi alat bukti itu adalah sesuatu yang sebelum diajukan ke persidangan memang sudah berfungsi sebagai alat bukti. Misalnya saja akta notaris yang belum diajukan sebagai alat bukti di persidangan sudah merupakan alat bukti tulisan yang otentik.

Akta ialah alat bukti berupa tulisan dan/atau sebaliknya yaitu tulisan yang sengaja dibuat untuk dipergunakan sebagai alat pembuktian. Kitab Undang-Undang Hukum Perdata (selanjutnya disebut KUH Perdata) membagi alat bukti tulisan (schrifftelijke bewijs, written evidence) menjadi dua macam sebagaimana diatur di dalam Pasal 1867, yaitu yang berupa tulisan-tulisan otentik maupun yang berupa tulisan-tulisan yang dibuat di bawah tangan. Akta yang dibuat oleh notaris diklasifikasikan ke dalam alat bukti tulisan yang otentik karena akta notaris di dalam pembuatannya dibuat sesuai dengan bentuk yang telah ditentukan oleh undang-undang dan dibuat oleh atau dihadapan notaris yang memang memiliki kekuasaan untuk itu di tempat wilayah kewenangan jabatannya. Ketika nantinya seorang notaris di dalam membuat suatu akta tidak memenuhi seluruh persyaratan di dalam membuat suatu akta otentik, maka akta yang dibuatnya tersebut akan kehilangan otentisitasnya sehingga menyebabkan hanya memiliki nilai pembuktian seperti akta di bawah tangan. ${ }^{18}$

Apabila para penghadap ingin membuat akta notaris sebagai alat bukti tulisan otentik yang akan digunakan di kemudian hari apabila terjadi sengketa, maka para penghadap tersebut datang menghadap kepada notaris di tempat wilayah kewenangan jabatannya. Para penghadap ketika menghadap kepada notaris wajib untuk membawa warkah atau segala dokumen-dokumen yang diperlukan untuk pembuatan akta. Notaris akan menanyakan mengenai maksud kedatangan para penghadap dan memberikan konsultasi mengenai kehendak dari para penghadap. Tidak lupa notaris wajib untuk memastikan kebenaran identitas dari para penghadap dan kemudian notaris akan menuangkan kehendak para penghadap ke dalam minuta akta. Setelah minutanya selesai maka notaris wajib untuk membacakannya kembali kepada para penghadap dengan menerangkan dan memberikan penjelasan mengenai isi dan maksud dari setiap pasal di dalam minuta akta, termasuk memberikan informasi mengenai peraturan perundang-undangan yang berhubungan dengan akta. ${ }^{19}$

Seluruh proses tersebut di atas wajib untuk disaksikan oleh sekurang-kurangnya dua orang saksi yang memenuhi syarat. Kemudian akan dilakukan pembubuhan tanda tangan, dimulai dari pembubuhan tanda tangan para penghadap, diikuti dengan tanda tangan saksi-saksi, dan yang terakhir adalah tanda tangan dari notaris. Ketika nantinya terdapat keadaan bahwa penghadap tidak bisa membubuhkan tanda tangannya pada

${ }^{17}$ Handayani, T., Yunanto, S., \& HUM, M. (2009). Pengakuan Tanda Tangan Pada Suatu Dokumen Elektronik di Dalam Pembuktian Hukum Acara Perdata di Indonesia. Universitas Diponegoro, h. 53.

${ }^{18}$ Puryatma, P. I. M. Op.cit, hlm. 4.

${ }^{19}$ Flora, H. S. (2012). Tanggung Jawab Notaris Pengganti dalam Pembuatan Akta. Kanun: Jurnal Ilmu Hukum, 14(2), h. 2. 
minuta akta, maka notaris dapat melekatkan cap jempol atau cap ibu jari dari penghadap pada minuta akta dan notaris wajib untuk menyertakan alasannya di dalam minuta akta mengapa penghadap yang bersangkutan tidak bisa membubuhkan tanda tangannya, misalnya saja alasannya dikarenakan penghadap tidak pernah belajar membaca dan menulis. Kemudian setelah itu semua maka yang terakhir adalah notaris wajib melekatkan cap jempol atau cap ibu jari dari para penghadap pada lembar sidik jari yang halamannya terpisah dari minuta akta.

Khusus mengenai pembubuhan tanda tangan maka di dalam KUH Perdata pengaturannya dapat ditemukan di dalam Buku Keempat mengenai Pembuktian dan Kedaluarsa pada Bab II Tentang Pembuktian dengan Tulisan. Di dalam ketentuan Pasal 1869 KUH Perdata mengatur terhadap akta otentik yang dibuat dengan adanya unsur ketidakwenangan atau ketidakcakapan dari pejabat umum yang membuatnya maupun karena terdapat cacat dalam bentuk akta yang bersangkutan, namun apabila para pihak telah menandatanganinya maka akta tersebut mempunyai kekuatan sebagai akta dibawah tangan. Kemudian di dalam ketentuan Pasal 1874 KUH Perdata mengatur pembubuhan cap jempol atau cap ibu jari disamakan dengan suatu penandatanganan, dengan syarat bahwa pada saat pembubuhan cap jempol atau cap ibu jari tersebut berlangsung maka harus terdapat pernyataan yang bertanggal dari notaris atau pejabat lain yang ditunjuk oleh undang-undang yang menyatakan bahwa orang yang membubuhkan cap jempol atau cap ibu jarinya tersebut dikenal olehnya atau telah diperkenalkan kepadanya, dengan sebelumnya telah memberikan penjelasan mengenai isi akta dan bahwa kemudian cap jempol atau cap ibu jari tersebut dibubuhkan pada tulisan di hadapan pejabat yang bersangkutan.

Kemudian mengenai pembubuhan tanda tangan di dalam UUJN Perubahan diatur di dalam ketentuan Pasal 44 ayat (1) yang mengatur suatu akta wajib untuk segera ditandatangani oleh para penghadap, saksi-saksi, dan yang terakhir adalah notaris segera setelah notaris membacakan akta tersebut. Namun ketentuan tersebut terdapat pengecualian, dimana ketika nantinya terdapat suatu keadaan bahwa penghadap tidak dapat membubuhkan tanda tangannya pada akta tersebut, maka notaris wajib menguraikan alasannya pada minuta akta mengapa penghadap yang bersangkutan tidak dapat membubuhkan tanda tangannya.

Peraturan perundang-undangan yang berlaku di Indonesia khususnya di dalam KUH Perdata maupun di dalam UUJN dan UUJN Perubahan tidak terdapat pasal yang mengatur mengenai pembubuhan tanda tangan yang berubah-ubah oleh penghadap di dalam pembuatan akta di hadapan notaris. Bahwa di dalam membubuhkan suatu tanda tangan di hadapan notaris tidak jarang seorang penghadap memiliki tanda tangan yang berbeda atau berubah-ubah dari tanda tangan yang sebelumnya telah dipergunakannya. Ada beberapa alasan mengapa sampai terjadi perbedaan atau perubahan terhadap tanda tangan dari seorang penghadap. Perubahan tanda tangan dari seorang penghadap bisa berasal dari kemauan penghadap itu sendiri, dimana misalnya saja setelah penghadap tersebut berkonsultasi dengan seorang ahli feng shui, penghadap tersebut kemudian ingin merubah tanda tangannya dengan maksud untuk menjadi lebih baik. Perubahan tanda tangan berikutnya juga bisa terjadi disebabkan karena kondisi dari penghadap yang tegang sehingga menyebabkan tangannya gemetar pada saat membubuhkan tanda tangannya di hadapan notaris. Perubahan tanda tangan 
bisa juga disebabkan karena penghadap yang bersangkutan pernah mengalami kecelakaan atau menderita suatu penyakit yang menyebabkan penghadap tersebut secara fisik kehilangan kemampuannya untuk menulis secara sempurna dan tentunya juga akan berpengaruh terhadap tanda tangan yang akan dibubuhkannya. Dan yang terakhir adalah ada kemungkinan bahwa terjadinya perubahan tanda tangan dari seorang penghadap disebabkan karena jauhnya jarak waktu diantara penandatanganan akta yang satu dengan penandatangan akta yang lainnya. ${ }^{20}$ Ada berbagai alasan yang menyebabkan mengapa seorang penghadap sampai bisa memiliki tanda tangan yang berbeda atau berubah-ubah, namun terdapat kekosongan norma di dalam peraturan perundang-undangan yang berlaku di Indonesia yang mengatur mengenai hal tersebut.

\subsection{Akibat Hukum Penggunaan Tanda Tangan Berubah-Ubah oleh Penghadap di dalam Pembuatan Akta Notaris \\ 3.2.1 Akibat Hukum Terhadap Akta Notaris yang Dibuat oleh Penghadap yang Memiliki Tanda Tangan Berubah-Ubah}

Akta notaris pada dasarnya merupakan suatu perjanjian yang memuat kehendak dari masing-masing penghadap. Istilah "perjanjian" dalam hukum perjanjian merupakan kesepadanan dari kata "ovreenkomst" dalam bahasa Belanda atau istilah "agreement" dalam bahasa Inggris. Di dalam kamus hukum istilah perjanjian dimaknai sebagai suatu persetujuan secara tertulis atau lisan yang dibuat dua pihak atau lebih dimana masing-masing berjanji akan mentaati apa yang tersebut dalam persetujuan itu sebagai kesepakatan bersama. Di dalam Pasal 1313 KUH Perdata mengatur suatu perjanjian adalah suatu perbuatan dimana satu orang atau lebih mengikatkan dirinya terhadap satu orang atau lebih. Dengan demikian maka dengan adanya suatu perjanjian maka akan mengikat para pihak secara hukum, untuk mendapatkan hak atau melaksanakan kewajiban yang ditentukan dalam perjanjian itu. Dengan adanya perjanjian berbentuk akta notaris tersebut maka akan memberikan kepastian bagi penyelesaian sengketa yang mungkin timbul di kemudian hari dan perjanjian berbentuk akta notaris tersebut dapat ditujukan untuk memperjelas suatu hubungan hukum.

Di dalam membuat akta notaris yang pada dasarnya merupakan suatu perjanjian yang memuat kehendak dari masing-masing penghadap terdapat tiga unsur penting yang termuat di dalam perjanjian tersebut. Unsur pertama adalah unsur esensialia, yaitu unsur yang wajib ada di dalam suatu perjanjian, sifat yang menentukan atau menyebabkan perjanjian itu tercipta (constructive oordeel). Seluruh unsur-unsur pokok dari suatu perjanjian harus dimuat di dalamnya dan apabila salah satu unsur pokok tidak ada maka perjanjian menjadi timpang dan perjanjian dianggap tidak pernah ada dan tidak mempunyai akibat hukum. Unsur kedua yaitu unsur naturalia, yaitu unsur yang sudah diatur di dalam undang-undang dan berlaku untuk setiap perjanjian, apabila para pihak tidak mengaturnya. Yang terakhir adalah unsur aksidentalia, yaitu suatu peristiwa yang dituangkan dalam suatu perjanjian yang nanti ada atau tidak ada peristiwa mana menjadi unsur aksidentalia mengikat para pihak. Dari ketiga unsur diatas maka agar suatu perjanjian dapat dijalankan maka unsur yang harus ada atau menjadi bagian inti (wezenlijk oordeel) adalah unsur esensialia, sedangkan apabila unsur

${ }^{20}$ Mertokusumo, S. Op.cit, h. 152. 
naturalia dan unsur aksidentalia merupakan hanya sebagai pelengkap perjanjian saja karena bukan merupakan bagian inti (nonn wezenlijk oordeel). ${ }^{21}$

Hukum acara perdata di Indonesia yang dicari adalah suatu kebenaran formal, sehingga tujuan para penghadap menuangkan kehendaknya dalam bentuk perjanjian atau akta yang dibuat di hadapan notaris adalah agar apabila nantinya terdapat sengketa di kemudian hari maka akta tersebut dapat dijadikan alat bukti tertulis yang kuat yaitu sebagai suatu akta otentik. ${ }^{22}$ Mengingat suatu akta notaris pada dasarnya adalah suatu perjanjian yang memuat kehendak para penghadap, maka di dalam pembuatan suatu akta di hadapan notaris wajib untuk memenuhi ketentuan Pasal 1320 KUH Perdata yaitu mengatur mengenai syarat sahnya suatu perjanjian, yang meliputi:

1. Diantara mereka yang mengikatkan dirinya telah terdapat suatu kesepakatan (consensus);

2. Terdapat kecakapan dari para pihak untuk membuat suatu perjanjian;

3. Mengenai suatu hal tertentu; dan

4. Suatu sebab yang halal (tidak terlarang).

Keempat syarat tersebut diatas merupakan suatu syarat yang bersifat komulatif atau bukan bersifat limitatif yang artinya adalah di dalam membuat suatu perjanjian atau akta di hadapan notaris wajib untuk memenuhi keseluruhan syarat sahnya suatu perjanjian tersebut diatas dan tidak boleh ada yang tidak terpenuhi. Apabila ada salah satu syarat saja yang tidak tepenuhi maka masing-masing syarat tersebut mempunyai akibat hukum yang berbeda-beda. Akibat hukum adalah akibat dari suatu tindakan yang dilakukan oleh pelaku dan hal tersebut diatur oleh hukum. Tindakan yang dilakukan ini dinamakan tindakan hukum. Jadi dengan lain perkataan akibat hukum adalah akibat dari suatu tindakan hukum. ${ }^{23}$

Syarat pertama dan syarat kedua dari sahnya suatu perjanjian menurut Pasal 1320 KUH Perdata dikenal juga dengan syarat subjektif perjanjian. Adapun akibat hukum apabila tidak terpenuhinya syarat subjektif ini di dalam membuat suatu perjanjian atau akta di hadapan notaris adalah membawa akibat hukum akta notaris tersebut dapat dibatalkan keberadaannya (vernietigbaarheid). Ketika nantinya unsur subjektif dari perjanjian tidak terpenuhi maka bagi pihak yang berkepentingan dapat mengajukan pembatalan ataupun tidak kepada pengadilan. Sedangkan syarat ketiga dan keempat dari sahnya suatu perjanjian menurut Pasal 1320 KUH Perdata dikenal juga dengan syarat objektif perjanjian. Adapun akibat hukum apabila tidak terpenuhinya syarat objektif ini di dalam membuat suatu perjanjian atau akta di hadapan notaris adalah membawa akibat hukum akta notaris tersebut menjadi batal demi hukum yaitu keberadaan dari akta notaris yang bersangkutan dianggap tidak pernah ada (nietigbaarheid). ${ }^{24}$

${ }^{21}$ Artadi, I. K. \& Putra, I. D. N. R. A. (2014). Implementasi Ketentuan-Ketentuan Hukum Perjanjian ke dalam Perancangan Kontrak. Denpasar: Udayana University Press, h. 36.

22 Palit, R. C. (2015). Kekuatan Akta di Bawah Tangan Sebagai Alat Bukti di Pengadilan. Lex Privatum, 3(2), h. 139.

${ }^{23}$ Soeroso, R. (2013). Pengantar Ilmu Hukum. Jakarta: Sinar Grafika, h. 295.

${ }^{24}$ Maxellia, L. (2013). Tinjauan Yuridis Tentang Kebatalan dan Pembatalan Akta Notaris dalam Prespektif Undang-undang Nomor 30 Tahun 2004 Tentang Jabatan Notaris (Doctoral dissertation, Universitas Sebelas Maret), h. 12. 
Mengenai pembubuhan tanda tangan yang berubah-ubah oleh penghadap di dalam pembuatan suatu akta di hadapan notaris, maka ketika akta tersebut dibuat oleh para penghadap yang telah terjadi kesepakatan di antara mereka yang membuatnya, mereka sebagai penghadap telah memenuhi syarat untuk membuat suatu perjanjian atau akta, dan perjanjian atau akta yang dibuatnya tersebut telah mengenai suatu pokok persoalan tertentu, sehingga berdasarkan hal tersebut tidak dapat dikatakan bahwa pembubuhan tanda tangan yang berubah-ubah oleh penghadap di dalam pembuatan suatu akta di hadapan notaris tidak memenuhi syarat pertama, syarat kedua, dan syarat ketiga dari sahnya suatu perjanjian menurut Pasal 1320 KUH Perdata. Syarat keempat dari sahnya suatu perjanjian juga tidak dapat dikatakan tidak terpenuhi dengan adanya pembubuhan tanda tangan yang berubah-ubah oleh penghadap di dalam pembuatan suatu akta di hadapan notaris. Khusus mengenai syarat keempat maka suatu sebab dikatakan tidak halal atau terlarang adalah ketika bertentangan dengan undangundang, kesusilaan, dan ketertiban umum. Sudah jelas bahwa pembubuhan tanda tangan yang berubah-ubah oleh penghadap di dalam pembuatan suatu akta di hadapan notaris tidaklah bertentengan dengan kesusilaan dan ketertiban umum, karena sesuatu dianggap bertentangan dengan kesusilaan ketika sesuatu tersebut melanggar norma kesusilaan mengenai penghargaan terhadap martabat manusia dan sesuatu dianggap bertentangan dengan ketertiban umum ketika sesuatu tersebut memiliki dampak yang luas kepada masyarakat. Pembubuhan tanda tangan yang berubah-ubah oleh penghadap di dalam pembuatan suatu akta di hadapan notaris juga tidak dapat dikatakan bahwa telah bertentangan dengan ketentuan peraturan perundang-undangan yang berlaku karena peraturan perundang-undangan yang berlaku di Indonesia khususnya di dalam KUH Perdata maupun di dalam UUJN dan UUJN Perubahan tidak terdapat pasal yang mengatur mengenai hal tersebut.

Telah terjadi suatu kekosongan norma dimana tidak terdapat pasal di dalam peraturan perundang-undangan yang berlaku di Indonesia yang mengatur mengenai akibat hukum pembubuhan tanda tangan yang berubah-ubah oleh penghadap di dalam pembuatan suatu akta di hadapan notaris. Di dalam ilmu hukum untuk mengisi suatu kekosongan hukum maka salah satu cara yang dapat ditempuh adalah dengan melakukan konstruksi hukum, yang mana konstruksi hukum sendiri dapat dibedakan ke dalam tiga bentuk yaitu melalui penafsiran analogi, penghalusan hukum, dan argumentum a contrario. Untuk dapat mengetahui akibat hukum dari pembubuhan tanda tangan yang berubah-ubah oleh penghadap di dalam pembuatan suatu akta di hadapan notaris maka akan dilakukan konstruksi hukum dengan menggunakan penafsiran analogis. Penafsiran analogis adalah penafsiran dari suatu peraturan hukum dengan memberi ibarat atau kias pada kata-kata tersebut dengan asas hukumnya, sehingga suatu peristiwa yang sebenarnya tidak dapat dimasukkan lalu dianggap sesuai dengan bunyi peraturan yang bersangkutan. Pada dasarnya penafsiran analogis ini dilakukan dengan memperluas berlakunya ketentuan hukum dari peraturan perundangundangan yang bersangkutan. ${ }^{25}$ Adapun penafsiran analogis yang dimaksud adalah dengan memperhatikan ketentuan Pasal 1875 dan 1876 KUH Perdata. Pasal 1875 KUH Perdata pada pokoknya mengatur terhadap suatu tulisan di bawah tangan yang orang yang membuatnya telah mengakui kebenarannya, maka bagi orang yang menandatanganinya tersebut dapat dijadikan sebagai bukti lengkap seperti suatu akta

${ }^{25}$ Soeroso. R. Op.cit, h. 112. 
otentik. Kemudian Pasal 1876 KUH Perdata pada pokoknya mengatur apabila ada seseorang yang mengajukan tuntutan terhadap suatu akta di bawah tangan, maka terhadap orang yang menandatangani akta di bawah tangan tersebut wajib untuk secara tegas mengakui ataupun memungkiri tanda tangannya. Apabila dilakukan penafsiran analogis dengan cara memperluas pengaturan di dalam pasal-pasal tersebut diatas maka mengenai keabsahan dari suatu tanda tangan adalah dilihat berdasarkan adanya pengakuan untuk membenarkan dari orang yang membubuhkan tanda tangan tersebut. ${ }^{26}$ Dalam hal ada penghadap yang membuat akta di hadapan notaris dengan menggunakan tanda tangan yang berbeda atau berubah-ubah maka hal tersebut tetap dibenarkan oleh hukum. Tanda tangan yang berbeda atau berubah-ubah dibenarkan oleh hukum sepanjang penghadap yang membubuhkan tanda tangannya tersebut membenarkan bahwa itu adalah tanda tangannya. Karena hukum telah membenarkan bahwa penghadap dapat menggunakan tanda tangan yang berubah-ubah di dalam pembuatan akta notaris, maka akibat hukum terhadap akta notaris yang dibuat adalah akta notaris tersebut tetap sah untuk digunakan sebagai alat bukti tulisan yang otentik apabila terjadi sengketa di kemudian hari. Yang perlu diperhatikan bahwa yang tidak dapat digunakan sebagai alat bukti tulisan adalah akta yang ditandatangani oleh orangorang yang tidak cakap di dalam melakukan perbuatan hukum, bukan oleh penghadap yang memiliki tanda tangan berbeda atau berubah-ubah.

\subsubsection{Kekuatan Hukum Pembuktian dari Akta yang Sebelumnya Telah Terlebih Dahulu Ditandatangani oleh Penghadap}

Di dalam hukum acara perdata baik oleh penggugat maupun oleh tergugat untuk membuktikan sesuatu kebenaran hukum di depan pengadilan maka dibutuhkan alat bukti untuk membuktikannya. Menurut Paton maka alat bukti dapat dibedakan menjadi alat bukti yang bersifat oral, documentary, dan material. Alat bukti yang bersifat oral merupakan kata-kata yang diucapkan oleh seorang di persidangan, yaitu kesaksiannya tentang sesuatu peristiwa. Termasuk di dalam alat bukti yang bersifat documentary adalah surat. Sedangkan termasuk dalam alat bukti yang bersifat material adalah barang fisik lainnya selain dokumen. Alat bukti material ini disebut juga demonstrative evidence. ${ }^{27}$ Berdasarkan ketentuan Pasal 1866 KUH Perdata maka di dalam hukum acara perdata alat bukti dapat dibedakan menjadi:

1. Bukti tulisan;

2. Bukti dengan saksi-saksi;

3. Persangkaan-persangkaan;

4. Pengakuan;

5. Sumpah.

Alat bukti tertulis adalah alat bukti yang berada pada urutan pertama di dalam hukum acara perdata yang merupakan alat bukti terpenting dan paling utama dibandingkan dengan alat bukti yang lain. Ditambah dengan kenyataan pada masa sekarang dimana semua perbuatan hukum dicatat atau dituliskan di dalam berbagai bentuk surat yang sengaja dibuat untuk itu. Berkaitan dengan hal tersebut maka aspek yang harus terpenuhi agar suatu tulisan bisa dijadikan sebagai suatu alat bukti tertulis adalah:28

\footnotetext{
${ }^{26}$ Harahap, M. Y. Op.cit, h. 561.

${ }^{27}$ Mertokusumo, S. Op.cit, h. 150.

${ }^{28}$ Harahap, M. Y. Op.cit, h. 561.
} 
1. Memuat tanda bacaan berupa aksara.

Inilah syarat pertama yaitu tulisan atau surat terdiri dari tanda bacaan dalam bentuk aksara, tidak dipersoalkan aksaranya dalam bahasa apa. Semua diakui dan sah sebagai aksara yang berfungsi sebagai tanda bacaan untuk mewujudkan bentuk tulisan atau surat sebagai alat bukti.

2. Disusun berupa kalimat sebagai pernyataan.

Agar aksara tersebut dapat berbentuk menjadi tulisan atau surat maupun akta, maka harus disusun berbentuk kalimat sebagai ekspresi atau pernyataan cetusan pikiran atau kehendak orang yang menginginkan perbuatannya atau rangkaian kalimat tersebut sedemikian rupa susunan dan isinya dapat dimengerti dengan jelas oleh yang membacanya sesuai dengan apa yang dikehendaki dalam surat tersebut.

3. Ditulis pada bahasa tulisan.

Walaupun pada masa sekarang yang paling umum tulisan ditemukan di atas kertas, namun menurut hukum bukan hanya tulisan yang ditulis pada kertas saja yang dapat dijadikan alat bukti dalam berperkara di pengadilan, tetapi meliputi juga tulisan yang tercantum pada bahan di luar kertas. Misalnya saja pada masa lalu ada tulisan yang ditulis pada kulit kayu maupun bambu.

4. Ditandatangani pihak yang membuat.

Syarat ini merupakan ketentuan yang cukup penting, dimana suatu surat atau tulisan yang memuat pernyataan atau kesepakatan yang jelas dan terang, tetapi tidak ditandatangani oleh yang membuatnya maka ditinjau dari segi hukum pembuktian tidak sempurna sebagai surat sehingga tidak sah dipergunakan sebagai alat bukti tulisan.

5. Foto dan peta bukanlah tulisan.

Foto dan peta tidak termasuk kedalam surat, karena keduanya bukan aksara yang berfungsi sebagai tanda bacaan. Meskipun foto atau peta mampu memberi kesan, bahkan penjelasan tentang hal yang tertera di dalamnya tidak dapat digolongkan sebagai tulisan, oleh karena itu tidak sah diajukan sebagai alat bukti tulisan. Lagipula menurut sifatnya foto dan peta tidak mengandung tanda tangan sehingga tidak memenuhi syarat sebagai alat bukti tulisan. Namun pada perkembangan hukum pembuktian foto dan peta sudah dapat diterima sebagai alat bukti, meskipun tidak dikategorikan sebagai alat bukti tulisan, sepanjang foto dan peta tersebut mempunyai konektisitas yang erat dengan perkara yang disengketakan.

6. Mencantumkan tanggal.

Surat yang sempurna bernilai sebagai suatu alat bukti tulisan selain terdapat tanda tangan juga wajib mencantumkan tanggal penandatanganannya. Meskipun secara yuridis surat yang tidak bertanggal tidak kehilangan fungsinya sebagai alat bukti, namun hal tersebut dapat dianggap sebagai cacat yang melemahkan eksistensinya sebagai alat bukti, sebab tanpa tanggal maka akan sangat sulit untuk menentukan kepastian pembuatan dan penandatangannya sehingga memberi peluang besar bagi pihak lawan untuk menyangkal kebenaran pembuatannya. Sehingga untuk mendukung kepastian pembuatannya harus dibantu oleh salah satu alat bukti yang lain, bisa dengan saksi, persangkaan, atau dengan sumpah tambahan (supplatoir eed).

Tujuan dari dibuatnya akta di hadapan notaris oleh para penghadap adalah agar apabila nantinya terdapat sengketa di kemudian hari maka akta notaris tersebut dapat dijadikan alat bukti tertulis yang kuat yaitu sebagai suatu akta otentik. Adapun aspek yang harus dipenuhi agar suatu akta notaris memenuhi kriteria sebagai suatu akta otentik sebagaimana di atur di dalam Pasal 1868 KUH Perdata adalah: 
1. Akta notaris sebagai suatu akta otentik dibuat dalam bentuk yang ditentukan oleh undang-undang.

2. Akta notaris sebagai suatu akta otentik wajib dibuat oleh atau dihadapan notaris yang berkedudukan sebagai seorang pejabat umum yang ditunjuk untuk itu.

3. Notaris tersebut harus mempunyai kewenangan untuk itu. Kewenangan seorang notaris di dalam membuat akta melekat pada jabatan yang dipangkunya, hal mana telah diatur di dalam UUJN maupun UUJN Perbubahan. Kewenangan tersebut meliputi:

a. Kewenangan mengenai subjeknya sebagaimana diatur di dalam Pasal 52 ayat (1) UUJN;

b. Kewenangan mengenai objeknya, yaitu sejauh akta otentik tersebut tidak dikhususnya menjadi kewenangan dari pejabat umum lainnya maka notaris berwenang untuk membuatnya;

c. Kewenangan mengenai waktu, yaitu notaris sebagai pejabat umum dapat membuat akta otentik kapan saja tidak mengenal batas waktu kecuali pada saat sedang cuti resmi dari jabatannya sebagaimana diatur di dalam Pasal 32 ayat (1) UUJN Perubahan; dan

d. Kewenangan mengenai tempat yang notaris hanya dapat membuat akta otentik di wilayah kewenangan jabatannya yaitu meliputi satu provinsi sebagaimana di atur di dalam Pasal 18 ayat (2) UUJN.

Ketiga unsur dan keempat kewenangan tersebut diatas bersifat komulatif yang berarti harus tepenuhi semuanya dan tidak boleh ada yang dilanggar agar suatu akta notaris benar-benar dapat dijadikan sebagai alat bukti tertulis yang otentik. Apabila terdapat satu unsur saja yang dilanggar dan tidak terpenuhi maka akan membawa akibat hukum akta notaris yang bersangkutan akan kehilangan otentisitasnya sebagai suatu alat bukti yang otentik dan hanya akan memiliki nilai pembuktian seperti akta di bawah tangan.

Peraturan perundang-undangan yang berlaku di Indonesia khususnya pengaturan di dalam KUH Perdata maupun di dalam UUJN dan UUJN Perubahan tidak terdapat pasal yang mengatur mengenai kekuatan hukum pembuktian dari akta yang sebelumnya telah terlebih dahulu ditandatangani oleh penghadap yang memiliki tanda tangan yang berbeda atau berubah-ubah. Dengan melakukan konstruksi hukum melalui penggunaan penafsiran analogis terhadap ketentuan Pasal 1875 dan 1876 KUH Perdata sebagaimana telah dibahas pada bagian sebelumnya, maka mengenai keabsahan dari suatu tanda tangan adalah dilihat berdasarkan adanya pengakuan untuk membenarkan dari orang yang membubuhkan tanda tangan tersebut. ${ }^{29}$ Tanda tangan yang berbeda atau berubah-ubah dibenarkan oleh hukum sepanjang penghadap yang membubuhkan tanda tangannya tersebut membenarkan bahwa itu adalah tanda tangannya. Karena menurut hukum keabsahan suatu tanda tangan dilihat berdasarkan adanya pengakuan untuk membenarkan dari orang yang membubuhkan tanda tangannya, terhadap akta yang sebelumnya telah terlebih dahulu ditandatangani oleh penghadap yang memiliki tanda tangan berbeda atau berubah-ubah maka menurut hukum tetap sah sebagai suatu akta notaris sepanjang penghadap yang bersangkutan membenarkan bahwa tanda tangan tersebut memang benar tanda tangan miliknya, sehingga kekuatan hukum pembuktian dari akta tersebut adalah sempurna sebagai

${ }^{29}$ Harahap, M. Y. Op.cit, h. 561. 
suatu alat bukti tertulis yang otentik (volledig bewijsracht). Yang di maksud dengan kekuatan hukum pembuktian yang sempurna adalah alat bukti tersebut sudah tidak perlu lagi dilengkapi atau ditunjang dengan alat bukti lainnya.

Apabila nantinya penghadap yang memiliki tanda tangan berbeda atau berubah-ubah tersebut memungkiri atau tidak mengakui bahwa itu adalah tanda tangan miliknya maka beban pembuktian berada pada penghadap yang bersangkutan dan hakim yang akan menilainya. ${ }^{30} \mathrm{Hal}$ ini didasarkan pada ketentuan Pasal $1877 \mathrm{KUH}$ Perdata yang pada pokoknya mengatur apabila seseorang memungkiri atau tidak mengakui tanda tangan miliknya maka hakim wajib untuk memerintahkan agar tanda tangan tersebut diperiksa di hadapan pengadilan. Pengujian terhadap keaslian tanda tangan dilakukan pemeriksaan di hadapan pengadilan untuk menentukan kebenarannya.

Terhadap notaris apabila nantinya di kemudian hari terdapat penghadap yang memungkiri tanda tangan yang berbeda atau berubah-ubah yang sesungguhnya memang penghadap tersebut yang membubuhkan tanda tangannya maka notaris disini hanya perlu membuktikan di hadapan pengadilan bahwa memang benar penghadap yang bersangkutan menghadap kepadanya dan notaris hanya perlu membuktikan kepada hakim bahwa memang benar penghadap tersebut yang langsung membubuhkan tanda tangan. Yang dimaksud dengan membuktikan adalah menyajikan fakta-fakta guna memberikan kepastian kepada hakim berkenaan dengan kebenaran sesuatu hal. ${ }^{31}$ Terlepas dari tanda tangan yang digunakan oleh penghadap terdapat perbedaan dan berubah-ubah ataupun tidak maka notaris tidak bertanggungjawab mengenai tanda tangan yang berubah-ubah tersebut. ${ }^{32}$ Notaris hanya perlu membuktikan kepada hakim bahwa pada tanggal yang sesuai dengan yang tertera pada minuta akta, dengan disaksikan oleh saksi-saksi yang disebutkan pada minuta akta, penghadap yang bersangkutan memang benar telah membubuhkan tanda tangan oleh dirinya sendiri di hadapan notaris. ${ }^{33}$ Dengan adanya pelekatan cap jempol atau cap ibu jari dari penghadap pada lembar sidik jari yang halamannya terpisah dari minuta akta, maka hal tersebut yang dapat menguatkan dan menjadi alat bukti bagi notaris pada saat memberi keterangan di hadapan persidangan, karena cap jempol atau cap ibu jari dari masing-masing orang akan berbeda-beda sehingga akan sulit bagi penghadap yang memiliki itikad tidak baik untuk memungkiri cap jempolnya tersebut. ${ }^{34}$

\footnotetext{
${ }^{30}$ Letsoin, V. (2010). Pengakuan Tandatangan Pada Dokumen Elektronik Dalam Pembuktian Hukum Acara Perdata Di Indonesia. Jurnal Sasi Vol, 16(3), h. 57.

${ }^{31}$ Yusrizal, K. (2008). Tinjauan Hukum Terhadap Kekuatan Pembuktian Akta Di Bawah Tangan Dihubungkan Dengan Kewenangan Notaris Dalam Pasal 15 Ayat (2) Uu Nomor 30 Tahun 2004 Tentang Jabatan Notaris (Doctoral dissertation, program Pascasarjana Universitas Diponegoro), h. 48 .

${ }^{32}$ Hendra, R. (2013). Tanggungjawab Notaris Terhadap Akta Otentik Yang Penghadapnya Mempergunakan Identitas Palsu di Kota Pekanbaru. Jurnal Ilmu Hukum, 3(01), h. 19.

${ }^{33}$ Triashari, N. W., \& Purwani, S. P. M. (2014). Analisis Yuridis Akta Di bawah Tangan Yang Di Waarmerking dan Di Legalisasi. Kertha Semaya, 2(02), h. 4.

${ }^{34}$ Harahap, M. Y. Op.cit, h. 562.
} 


\section{Kesimpulan}

Berdasarkan uraian-uraian yang telah dipaparkan pada bagian terdahulu, maka dapat ditarik kesimpulan sebagai berikut:

Pembubuhan tanda tangan oleh penghadap di dalam pembuatan akta di hadapan notaris mempunyai dua fungsi yaitu untuk mengindividualisir atau memberi ciri suatu akta dan juga berfungsi sebagai suatu pernyataan kemauan atau persetujuan. Ada berbagai alasan yang menyebabkan mengapa seorang penghadap sampai bisa memiliki tanda tangan yang berubah-ubah, namun peraturan perundang-undangan yang berlaku di Indonesia tidak terdapat pasal yang mengatur mengenai hal tersebut. Dengan melakukan penafsiran analogis dengan cara memperluas pengaturan di dalam Pasal 1875 dan 1876 KUH Perdata maka mengenai keabsahan dari suatu tanda tangan adalah dilihat berdasarkan adanya pengakuan untuk membenarkan dari orang yang membubuhkan tanda tangan tersebut. Tanda tangan yang berbeda atau berubah-ubah dibenarkan oleh hukum sepanjang penghadap yang membubuhkan tanda tangannya tersebut membenarkan bahwa itu adalah tanda tangannya, sehingga akibat hukum terhadap akta notaris yang demikian adalah tetap sah untuk digunakan sebagai alat bukti tulisan otentik yang memiliki kekuatan hukum pembuktian sempurna yang tidak perlu lagi dilengkapi atau ditunjang dengan alat bukti lainnya. Walaupun sesungguhnya peraturan perundang-undangan yang berlaku di Indonesia tidak melarang digunakannya tanda tangan berubah-ubah di dalam pembuatan akta notaris, namun kepada setiap penghadap yang akan membuat akta di hadapan notaris disarankan untuk tidak melakukan hal tersebut agar dapat meminimalisir potensi terjadinya permasalahan di kemudian hari. Mengingat belum adanya peraturan perundang-undangan yang mengatur secara tegas mengenai pembuatan akta notaris oleh penghadap yang memiliki tanda tangan berubah-ubah maka kepada pembentuk undang-undang disarankan untuk sudah seharusnya melakukan penyempurnaan kembali terhadap UUJN untuk lebih menjamin adanya kepastian hukum bagi masyarkat.

\section{Daftar Pustaka}

\section{Buku}

Artadi, I. K. \& Putra, I. D. N. R. A. (2014). Implementasi Ketentuan-Ketentuan Hukum Perjanjian ke dalam Perancangan Kontrak. Denpasar: Udayana University Press.

Harahap, M. Y. (2009). Hukum Acara Perdata Tentang Gugatan, Persidangan, Penyitaan, Pumbuktian, dan Putusan Pengadilan. Jakarta: Sinar Grafika.

Mertokusumo, S. (2009). Hukum Acara Perdata Indonesia. Yogyakarta: Liberty.

Puryatma, P. I. M. (2016). Teknik Dasar Pembuatan Akta Notaris. Denpasar: Tanpa Penerbit.

Soeroso, R. (2013). Pengantar Ilmu Hukum, Jakarta: Sinar Grafika.

Thong, T. K. (2011). Studi Notariat Serba-Serbi Praktek Notaris. Jakarta: PT. Ichtiar Baru Van Houve.

\section{Jurnal}

Arifin, J., \& Naf'an, M. Z. (2017). Verifikasi Tanda Tangan Asli Atau Palsu Berdasarkan Sifat Keacakan (Entropi). Jurnal Infotel, 9(1).

Flora, H. S. (2012). Tanggung Jawab Notaris Pengganti dalam Pembuatan Akta. Kanun: Jurnal Ilmu Hukum, 14(2). 
Handayani, T., Yunanto, S., \& HUM, M. (2009). Pengakuan Tanda Tangan Pada Suatu Dokumen Elektronik di Dalam Pembuktian Hukum Acara Perdata di Indonesia. Universitas Diponegoro.

Hendra, R. (2013). Tanggungjawab Notaris Terhadap Akta Otentik Yang Penghadapnya Mempergunakan Identitas Palsu di Kota Pekanbaru. Jurnal Ilmu Hukum, 3(01).

Letsoin, V. (2010). Pengakuan Tandatangan Pada Dokumen Elektronik Dalam Pembuktian Hukum Acara Perdata Di Indonesia. Jurnal Sasi Vol, 16(3).

Mahmoud, A. R. (2014). Implikasi Hukum Bagi Notaris Yang Tidak Melekatkan Sidik Jari Penghadap Pada Minuta Akta. Kumpulan Jurnal Mahasiswa Fakultas Hukum, 1(1).

Maxellia, L. (2013). Tinjauan Yuridis Tentang Kebatalan dan Pembatalan Akta Notaris dalam Prespektif Undang-undang Nomor 30 Tahun 2004 Tentang Jabatan Notaris (Doctoral dissertation, Universitas Sebelas Maret).

Mezak, M. H. (2006). Jenis, Metode dan Pendekatan Dalam Penelitian Hukum. Law Review: Fakultass Hukum Universitas Harapan, 5(3).

Palit, R. C. (2015). Kekuatan Akta di Bawah Tangan Sebagai Alat Bukti di Pengadilan. Lex Privatum, 3(2).

Prawira, M. A. S., \& Dewi, A. I. A. A. (2013). Kekuatan Pembuktian Akta Dibawah Tangan Yang Dilegalisasi Notaris Denpasar. Kertha Semaya, 1(05).

Suwignyo, H. (2009). Keabsahan Cap Jempol sebagai Pengganti Tanda Tangan dalam Pembuatan Akta Otentik. Notarius, 1(1).

Triashari, N. W., \& Purwani, S. P. M. (2014). Analisis Yuridis Akta Di bawah Tangan Yang Di Waarmerking dan Di Legalisasi. Kertha Semaya, 2(02).

Yusrizal, K. (2008). Tinjauan Hukum Terhadap Kekuatan Pembuktian Akta Di Bawah Tangan Dihubungkan Dengan Kewenangan Notaris Dalam Pasal 15 Ayat (2) Uu Nomor 30 Tahun 2004 Tentang Jabatan Notaris (Doctoral dissertation, program Pascasarjana Universitas Diponegoro). 